\title{
Species diversity of small mammals at Gunung Stong State Park, Kelantan, Malaysia
}

\author{
Vijaya Kumaran Jayaraj ${ }^{1}$, Nurul Farah Diyana Ahmad Tahir ${ }^{2}$, Noor Amirah Udin ${ }^{3}$, \\ Noor Farahin Kamarul Baharin ${ }^{4}$, Siti Katijah Ismail ${ }^{5}$ \& Siti Noor Azwa Zakaria ${ }^{6}$ \\ 1,2,3,4,5,6 Faculty of Agro Industry and Natural Resources, Universiti Malaysia Kelantan, Jeli Campus Locked bag No. 100, 17600 Jeli, \\ Kelantan, Malaysia \\ Email: ${ }^{1}$ jayaraj_vijayakumaran@yahoo.com (corresponding author), ${ }^{2}$ diyan_yana90@yahoo.com, ${ }^{3}$ nooramirahudin@yahoo.com, \\ ${ }^{4}$ noorfarahin_kamarulbaharin@rocketmail.com, ${ }^{5}$ sitikatijah_ismail@yahoo.com, ${ }^{6}$ azwa.zakaria@yahoo.com
}

Date of publication (online): 26 June 2012 Date of publication (print): 26 June 2012 ISSN 0974-7907 (online) | 0974-7893 (print)

Editor: Giovanni Amori

\section{Manuscript details:}

Ms \# 03015

Received 21 November 2011

Final received 09 April 2012

Finally accepted 08 May 2012

Citation: Jayaraj, V.K., N.F.D.A. Tahir, N.A.Udin N.F.K. Baharin, S.K. Ismail \& S.N.A. Zakaria (2012). Species diversity of small mammals at Gunung Stong State Park, Kelantan, Malaysia. Journal of Threatened Taxa 4(6): 2617-2628.

Copyright: (C) Vijaya Kumaran Jayaraj, Nuru Farah Diyana Ahmad Tahir, Noor Amirah Udin, Noor Farahin Kamarul Baharin, Siti Katijah Ismail \& Siti Noor Azwa Zakaria 2012. Creative Commons Attribution 3.0 Unported License. JoTT allows unrestricted use of this article in any medium for non-profit purposes, reproduction and distribution by providing adequate credit to the authors and the source of publication.

Author Contribution: VKJ is the corresponding author of this paper. He provided the funding, led the field work and overall writing of the manuscript. NFDAT, NAU, NFKB, SKI and SNAZ was part of the field survey team and they volunteered to co-author this paper and produced the first draft of the paper including the tabulation of results.

For Author Details and Acknowledgments See end of this article.

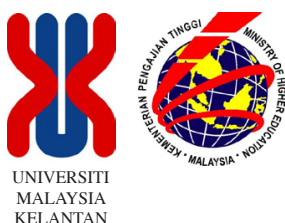

\section{(C) (1) (4)}

OPEN ACCESS | FREE DOWNLOAD
Abstract: A recent small mammal survey was conducted in Gunung Stong State Park. Standard mist nets, harp traps and cage traps were used to document diversity of small mammals in this new protected area. This study reports five new distributional records of bats in Gunung Stong State Park and a first record of Myotis muricola in Kelantan. The study also shows that Gunung Stong State Park is one of the three areas in Peninsular Malaysia where all four Cynopterus species that can be found in Peninsular Malaysia coexist. This protected area also has Maxomys rajah, M. whiteheadi and Niviventer cremoriventer which are currently listed as Vulnerable, highlighting this location as an important conservation area for small mammals. Continuous surveys are needed as information of small mammal diversity in Kelantan is still scarce, and this study is a part of a series of small mammal surveys that have been carried out in Kelantan.

Keywords: Gunung Stong State Park, Kelantan, new record, small mammals, species diversity.

\section{INTRODUCTION}

Gunung Stong State Park, Malaysia which covers an area of 21,950ha, is situated north west of Kelantan in the district of Kuala Krai (Maseri \& Mohd-Ros 2005). This state park is strategically positioned as part of a large forest block that includes the Titiwangsa Range, the BelumTemenggor and the Ulu Muda forests in Malaysia, and connects with the stretch of forests in Hala Bala Wildlife Sanctuary and the Bang Lang National Park in southern Thailand (Maseri \& Mohd-Ros 2005). This positioning, coupled with the buffering effect of various forests reserves around the area, is most suitable for fauna conservation as many iconic large mammals such as tigers, elephants, deer and leopards are found there (Zafir et al. 2005).

Gunung Stong State Park is also a good area for ecotourism. Its center of attraction is the Jelawang waterfall which is hailed as the highest waterfall in Southeast Asia (Yusoff et al. 2005). This state park also has iconic flora and fauna, that appeal to nature photographers, such as hornbills, banded leaf monkeys, colugo, the endemic Fan Palm Licuda stongensis, the endemic Bamboo Holtummochloa pubescens and Rafflesia kerrii (Latiff \& Faridah-Hanum 2005). Together with several mountain peaks such as Gunung Ayam, Gunung Tera and Gunung Stong, this place is suitable for a variety of recreational activities and has been listed in the 2006 Malaysian National Economic Plan as one of the top 10 special places for ecotourism.

According to Bourliere (1975), small mammals have adult weights 
ranging from $2 \mathrm{gm}$ to $5 \mathrm{~kg}$. The majority of species in this category are from the high diversity orders Rodentia and Chiroptera, and Lagomorpha, Insectivora and Scandentia are also in this group. The importance of Rodentia and Chiroptera in the ecology of the tropical rainforest in Southeast Asia is recognized, yet the small mammals of Kelantan are not well known, with records of surveys from EIA surveys on certain development projects such as the Pergau, Lebir and Negiri Dam Project (see Pue \& Latiff 2005) and surveys conducted by Zafir et al. (2005), Shukor et al. (2005) and Mariana et al. (2005). The objective of this study was to survey the diversity and abundance of small mammals in Gunung Stong State Park and add further information on the biodiversity of small mammals in Kelantan, Malaysia.

\section{MATERIALS AND METHODS}

The main sampling areas of this study were the Gunung Stong State Park headquarters and Gua Ikan (Image 1). Two trails near the park headquaters were chosen as sampling stations for bats. The first sampling station was Stong Trail $1\left(5^{\circ} 20.352^{\prime} N \& 101^{0} 58.503^{\prime} E\right.$, elevation 100-200 m) and the second sampling station was Stong Trail $3\left(5^{0} 20.353^{\prime} \mathrm{N} \& 101^{0} 58.505^{\prime} \mathrm{E}, 100\right.$ $200 \mathrm{~m})$. The vegetation at the first sampling station was hill vegetation with some bamboo plots, and the second sampling station was in the vicinity of the forest ecotone. A total of 10 mist nets and two harp-traps were used to capture bats. These nets and traps were placed in presumed flyways of bats at the sampling stations for four consecutive nights (2-4 March 2011). We also set up four additional nets near in Gua Ikan $\left(05^{\circ} 21.268^{\circ} \mathrm{N} \& 102^{\circ} 1.5483^{\prime} \mathrm{E}, 97 \mathrm{~m}\right)$ which are limestone caves that are found near the forest reserve.

For non-volant small mammals, two sites were

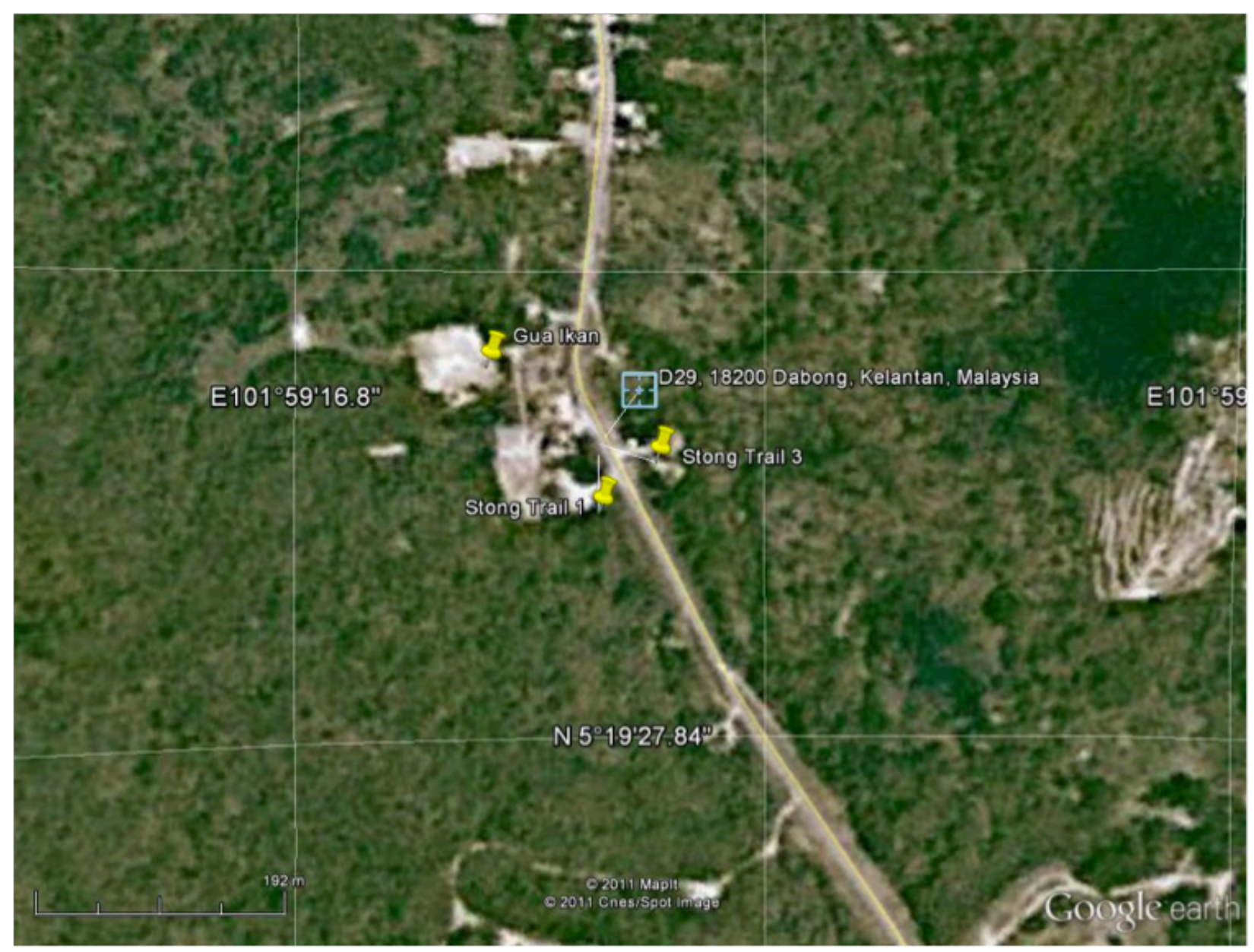

Image 1. Map of the study area (Source: Google Earth, 2011) 
chosen in the vicinity of the park headquarters $\left(5^{\circ} 20.352^{\prime} \mathrm{N} \& 101^{0} 58.503^{\prime} \mathrm{E}, 100-200 \mathrm{~m}\right)$ and Gua Ikan $\left(5^{\circ} 21.268^{\prime} \mathrm{N} \& 102^{\circ} 1.5483^{\prime} \mathrm{E}, 97 \mathrm{~m}\right)$. The vegetation at the sampling stations were: site $\mathrm{A}$ ) hill vegetation with some bamboo plots and river vegetation (park headquarters), and site B) limestone area (Gua Ikan). Non-volant small mammals were captured using cage traps and all traps were placed on the ground to target forest floor small mammals. A total of 100 cage traps baited with pineapple were used for this purpose and all traps were placed for four consecutive days (2-4 March 2011).

Captured animals were identified using keys from Francis (2008), and standard measurements were recorded. The diversity of small mammals for this survey was presented as list of species recorded and abundance was characterized by the capture rate of each species during this survey.

\section{RESULTS}

The cumulative species graph over days for bats is shown in Fig. 1. The graph is yet to reach an asymptotic level indicating that in-terms of sampling, there may still be species that are yet to be recorded. This also indicates that the netting effort of 52 net-nights was not adequate to sample the total chiroptera community in Kelantan. Table 1 shows the list of species caught, net-nights and capture rate of bats in this study and further comparison with the data from Mariana et al. (2005) and Shukor et al. (2005). This survey recorded 11 species of bats and the highest number of individuals caught was Cynopterus horsfieldii, followed by $C$. sphinx and the lowest capture rate were from Rhinolophus affinis, Tylonycteris robustula and Myotis muricola.

The species graph over days for non-volant mammals is shown in Fig. 2. The graph reached an asymptotic level on the $2^{\text {nd }}$ day $-3^{\text {rd }}$ day but the number of species trapped increased on the $4^{\text {th }}$ day of sampling indicating that the total trapping effort was
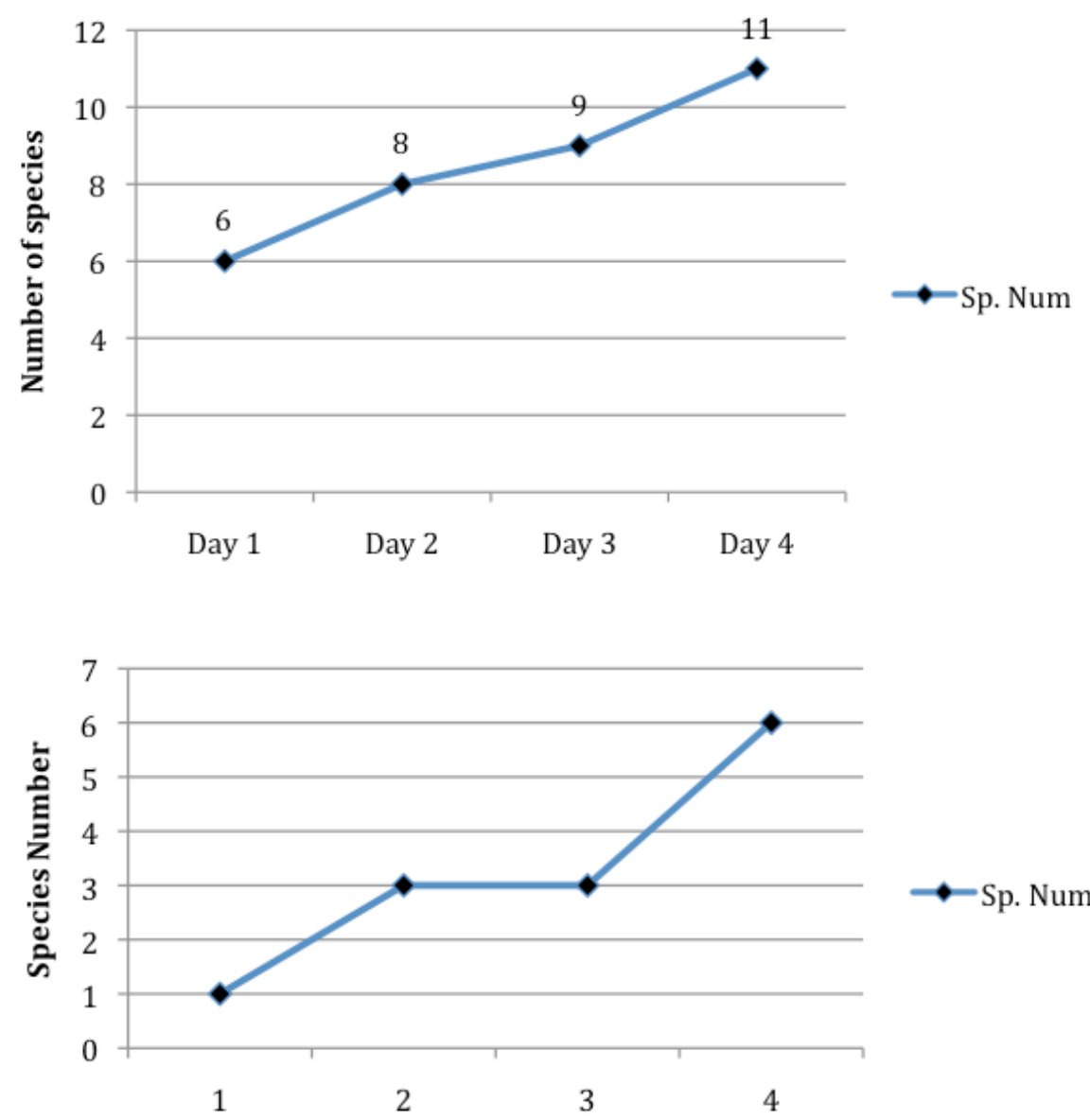

Figure 1. Cumulative frequency graph of bats in Mount Stong and Gua lkan
Figure 2. Cumulative Frequency Graph of Non-volant Small Mammals in Mount Stong and Gua Ikan 
Table 1. List of species caught, net nights and capture rate of bats in this study

\begin{tabular}{|c|c|c|c|c|c|c|}
\hline Species & Site A & Site B & Gua Ikan & total & Shukor et al. 2005 & Mariana et al. 2005 \\
\hline \multicolumn{7}{|l|}{ Family Pteropodidae } \\
\hline Cynopterus horsfieldii* & 5 & 30 & 3 & 38 & 0 & \\
\hline Cynopterus brachyotis & 6 & 4 & 1 & 11 & \multirow{2}{*}{$6^{a}$} & \multirow{2}{*}{$6^{\mathrm{a}}$} \\
\hline Cynopterus cf. brachyotis Forest & 3 & 4 & 3 & 10 & & \\
\hline Cynopterus sphinx $x^{*}$ & 1 & 12 & 1 & 14 & 0 & 0 \\
\hline Balionycteris maculata & 0 & 0 & 0 & 0 & 2 & 3 \\
\hline Penthetor Iucasi* & 1 & 0 & 0 & 1 & 0 & 0 \\
\hline Eonycteris spelaea* & 0 & 0 & 5 & 5 & 0 & 0 \\
\hline Macroglossus sobrinus & 0 & 5 & 0 & 5 & 19 & 19 \\
\hline Macroglossus minimus & 0 & 0 & 0 & 0 & 4 & 3 \\
\hline \multicolumn{7}{|l|}{ Family Nycteridae } \\
\hline Nycteris javanica & 0 & 0 & 0 & 0 & 1 & 1 \\
\hline \multicolumn{7}{|l|}{ Family Rhinolophidae } \\
\hline Rhinolophus trifoliatus & 0 & 0 & 0 & 0 & 1 & 1 \\
\hline Rhinolophus stheno & 0 & 0 & 0 & 0 & 9 & 9 \\
\hline Rhinolophus refulgens & 0 & 0 & 0 & 0 & 1 & 1 \\
\hline Rhinolophus affinis & 0 & 0 & 1 & 1 & 21 & 29 \\
\hline \multicolumn{7}{|l|}{ Family Hipposideridae } \\
\hline Hipposideros bicolor & 0 & 0 & 0 & 0 & 70 & 74 \\
\hline Hipposideros larvatus & 0 & 0 & 0 & 0 & 16 & 13 \\
\hline \multicolumn{7}{|l|}{ Family Vespertilionidae } \\
\hline Kerivoula hardwickii & 0 & 0 & 0 & 0 & 15 & 15 \\
\hline Kerivoula minuta & 0 & 0 & 0 & 0 & 6 & 6 \\
\hline Kerivoula papilosa & 0 & 0 & 0 & 0 & 17 & 16 \\
\hline Kerivoula pellucida & 0 & 0 & 0 & 0 & 2 & 2 \\
\hline Murina cylcotis & 0 & 0 & 0 & 0 & 3 & 3 \\
\hline Murina suilla & 0 & 0 & 0 & 0 & 4 & 4 \\
\hline Murina aenea & 0 & 0 & 0 & 0 & 1 & 0 \\
\hline Myotis ater & 0 & 0 & 0 & 0 & 2 & 3 \\
\hline Myotis muricola ${ }^{\star *}$ & 0 & 1 & 0 & 1 & 0 & 0 \\
\hline Tylonycteris pachypus & 0 & 4 & 0 & 4 & 2 & 2 \\
\hline Tylonycteris robustula & 0 & 1 & 0 & 1 & 4 & 4 \\
\hline Total no. of individuals & 16 & 61 & 13 & 91 & 216 & 214 \\
\hline No. of species & 5 & 7 & 6 & 11 & 21 & 20 \\
\hline No. of family & 2 & 2 & 2 & 3 & 5 & 5 \\
\hline Net-nights & 24 & 24 & 4 & 52 & 55 & 33 \\
\hline Capture rate & 1 & 3 & 3 & 2 & 4 & 7 \\
\hline
\end{tabular}

* - new record at Gunung Stong State Park; ** - New record for Kelantan based on Pue \& Latiff (2005), Mohd Zafir et al. (2005) and Mariana et al. (2005);

a - Note that Shukor et al. (2005) and Mariana et al. (2005) did not distinguish C. brachyotis from C. cf. brachyotis Forest.

not adequate to document non-volant small mammals diversity on the forest floor in the sampling stations. We recorded a total of six species of non-volant small mammals in this study with the highest number of individuals caught were Leopoldamys sabanus (six individuals) followed by Maxomys whiteheadi (two individuals).

\section{Species accounts}

Cynopterus brachyotis (Müller, 1838): This 
species has been recorded in open areas and agricultural plots in southern Thailand, Peninsular Malaysia and Borneo (Abdullah 2003; Abdullah et al. 1997a,b, 2000; Anwarali et al. 2007; Hall et al. 2002, 2004; Karim et al. 2004; Azlan et al. 2005; Jayaraj et al. 2011, 2012). In Borneo C. brachyotis is one of the most successful and dominant fruit bat in terms of capture rate and distribution. We netted this species near the forest fringe and near a small stream. This species is listed as Least Concern in the IUCN Red List of Threatened Species (Csorba et al. 2008) and Red List of Mammals for Peninsular Malaysia (DWNP 2010).

There has been ongoing research on the presence of several distinct lineages in this species and in southern Thailand, Peninsular Malaysia and Borneo a smaller form tentatively assigned as $C$. cf. brachyotis Forest has been identified (Abdullah 2003; Campbell et al. 2004, 2006, 2007; Jayaraj 2009; Fong 2011; Jayaraj et al. 2012). We took the liberty of separating the new form C. cf. brachyotis Forest as a separate account for future reference using methods described by Jayaraj et al. (2012).

Cynopterus cf. brachyotis Forest: This undescribed species has been known to occur in primary forests and old secondary forests in contrast with the habitat of $C$. brachyotis (Abdullah 2003). We caught $C$. cf. brachyotis Forest in the forest fringes in the same nets that netted C. brachyotis, indicating that these two species although occurs in contrasting habitats but may meet at forest fringes. This undescribed species (see Simmons 2005) is not listed in IUCN's Red List of Threatened Species (2008) and Red List of Mammals for Peninsular Malaysia (DWNP 2010).

Cynopterus horsfieldii Gray, 1843: This is a new record for Gunung Stong State Park. This species is known to be a forest dwelling Cynopterus, commonly caught at the ecotones and may occur sympatric with $C$. cf. brachyotis Forest but there are records of this species netted in oil palm plantations and in Pulau Tioman (Lim et al. 1999). The capture rate of this species was the highest in this study, which was highly in contrast when compared with trapping

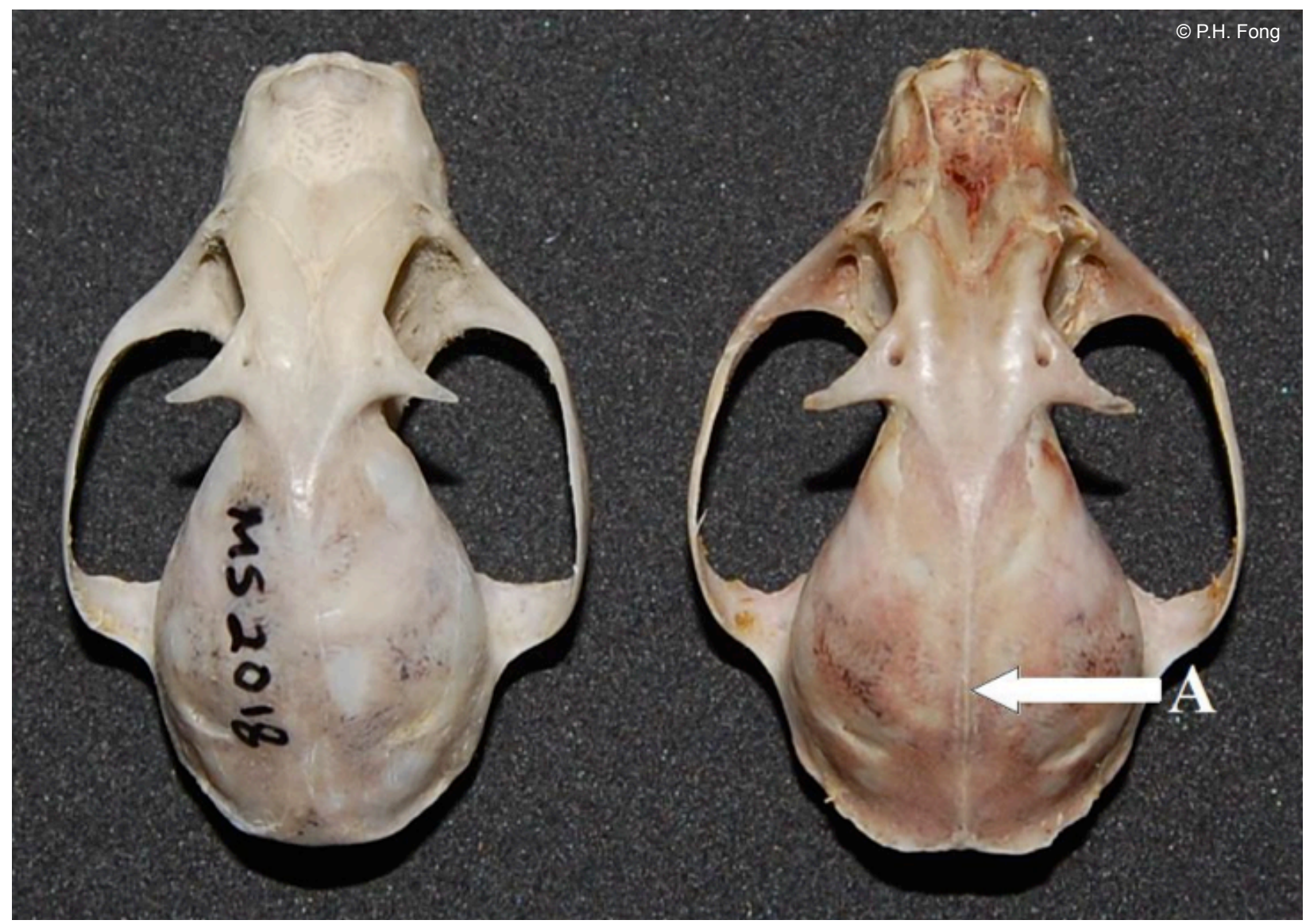

Image 2. Female $C$. horsfieldii (left) with less prominent sagittal crest versus male $C$. horsfieldii with prominent sagittal crest (A) 
results in similar vegetations in Borneo (see Jayaraj et al. 2011) whereas in Pahang the capture rate of this species is similar with $C$. brachyotis (see Lim et al. 2008). Individuals of this species were caught in all three forms of habitat (ecotones, hill forest and limestone areas). Sexual dimorphism of skulls was apparent, where in male skulls have more prominent sagittal crest compared to female skulls (Image 2). This species is listed as Least Concern in the IUCN Red List of Threatened Species (Bates et al. 2008a) and Red List of Mammals for Peninsular Malaysia (DWNP 2010).

Cynopterus sphinx (Vahl, 1797): This is a new record for Gunung Stong State Park. The social structure of $C$. sphinx was previously studied by Storz et al. (2000) and they found out that this species exhibits a polygynous mating system, with males having varying harem size from six to 13 females. Lim et al. (2008) suggested that the distribution pattern of C. sphinx should be investigated as little is known about the current distribution of this species in Malaysia. Clinal variation in terms of size of this species was discussed by Storz et al. (2001) and our observations (unpublished data) indicate that $C$. sphinx is not highly adaptable in Peninsular Malaysia incongruent with observations of Bates et al. (2008b). Although widespread the abundance of this species is determined by the type of vegetation sampled (Campbell et al. 2006). In Gunung Stong State Park the forearm length of this species was $74.52 \pm 3.87 \mathrm{~mm}$ and this species was netted in the hill vegetation and near bamboo plots beside the forest fringe. Struebig et al. (2005) netted this species near fruiting figs trees and this is commonly observed across Peninsular Malaysia with other Cynopterans. This species is listed as Least Concern in the IUCN Red List of Threatened Species (Bates et al. 2008b) and Red List of Mammals for Peninsular Malaysia (DWNP 2010).

Penthetor lucasi (Dobson, 1880): This is a new record for Gunung Stong State Park. Only one individual was caught near the forest fringe throughout the survey. This cave dwelling species normally roosts in large numbers and may have a population size up to 70,845 individuals [mark recapture model estimates in Wind Cave Nature Reserve Sarawak, Malaysia by Barapoi (2004)]. A recent study by Rahman \& Abdullah (2010) indicated that there are two or more morphologically distinct forms of $P$. lucasi from different localities in Sarawak. It is quite possible that such a distinct form also existed in Peninsular Malaysia. This species is listed as Least Concern in the IUCN Red List of Threatened Species (Bates et al. 2008c) and Red List of Mammals for Peninsular Malaysia (DWNP 2010).

Eonycteris spelaea (Dobson, 1871): This is a new record for Gunung Stong State Park. Five individuals of this species were caught near the limestone area throughout the survey. Daytime survey in the cave revealed that this species was abundant in the Gua Ikan. Previously, this species was netted at Gua Musang, Kelantan (Shabrina 1991). Mariana et al. (2005) and Shukor et al. (2005) did not record this species in their survey most probably because their nets were not placed near the cave. Anwarali et al. (2008) observed that individuals from Peninsular Malaysia versus Borneo had a genetic distance of $1 \%$. This species is listed as Least Concern in the IUCN Red List of Threatened Species (Francis et al. 2008) and Red List of Mammals for Peninsular Malaysia (DWNP 2010).

Macroglossus sobrinus K. Andersen, 1911: This species is common in many forest types in Malaysia but has been associated with flowering banana plots and mangrove areas. We collected five individuals of $M$. sobrinus near the river and similarly Shukor et al. (2005) and Mariana et al. (2005) collected 19 individuals of this species in their expeditions. This species is listed as Least Concern in the IUCN Red List of Threatened Species (Hutson et al. 2008).

Rhinolophus affinis Horsfield, 1823: Only one individual was caught in this survey near Gua Ikan. This highly adaptable and common species can be found in most protected areas in Malaysia and are generally abundant in most sites sampled. However, Lim et al. (2008) and Kingston et al. (2008) stated that this species is a common under-storey forest bat that is confined to caves. Shukor et al. (2005) collected 21 individuals of this species while Mariana et al. (2005) collected 29 individuals indicating high abundance of this species in Gunung Stong State Park. Approximately $4 \%$ in cyt-b genetic distance observed between Bornean individuals and a single individual from Thailand in Anwarali et al. (2008) and this may have some significance in this study as this individual from Gunung Stong State Park may have similar genetic difference with Bornean samples. This species is listed as Least Concern in the IUCN Red List of 
Threatened Species (Walston et al. 2008) and Red List of Mammals for Peninsular Malaysia (DWNP 2010).

Myotis muricola (Gray, 1846): This is a new record for Gunung Stong State Park and Kelantan. We netted this species near the bamboo plots but this species is generally netted in open areas, heath forest, peat swamps, streams and rivers near forest, and agricultural plots (Struebig et al. 2006; Francis 2008). The Red List of Mammals for Peninsular Malaysia (DWNP 2010) indicates that this species is widely distributed in peninsular Malaysia. Francis (2008) mentioned that this species maybe a complex species based on genetic analyses but diagnostic characters and appropriate names have yet to be assigned (see Anwarali et al. 2008). Only one individual was recorded throughout the survey and this species is listed as Least Concern in the IUCN Red List of Threatened Species (Bates et al. 2008d) and Red List of Mammals for Peninsular Malaysia (DWNP 2010).

Tylonycteris pachypus (Temminck, 1840): This species was netted near bamboo plots and a total of four individuals were collected throughout the survey. Shukor et al. (2005) collected only two individuals in their survey but we believe that this species maybe more abundant in Gunung Stong State Park based on the presence of many bamboo plots and observations of slit in the internodes of the bamboos. This species is listed as Least Concern in the IUCN Red List of Threatened Species (Bates et al. 2008e) and Red List of Mammals for Peninsular Malaysia (DWNP 2010).

Tylonycteris robustula Thomas, 1915: This is a species of bat associated with bamboos (Anwarali et al 2008; Francis 2008) and is a sister species with T. pachypus (Francis 2008). We collected only one individual of $T$. robustula in this survey, whereas Mariana et al. (2005) and Shukor et al. (2005) collected four individuals in their surveys. Similarly this species was netted in the same net as T. pachypus, reinforcing the idea that this species does share roosting sites with T. pachypus (Francis 2008). Francis (2008) did mention that there are differences in roost site selection of both species; T. robustula prefer large and dead bamboos whereas $T$. pachypus prefer live bamboo stems, but both species may share the same roost hole. This species is listed as Least Concern in the IUCN Red List of Threatened Species (Bates et al. 2008f) and Red List of Mammals for Peninsular Malaysia (DWNP 2010).
Maxomys surifer (Miller, 1900): We collected only one individual of $M$. surifer near Gua Ikan, but previously Shukor et al. (2005) collected three individuals of this species near the vicinity of site A (sampling site of present study). This species is the most abundant small mammal trapped in Huai Kha Khaeng Wildlife Sanctuary, central Thailand (Walker \& Rabinowitz 1992). M. surifer and M. rajah have rarely been caught in the same area but Shukor et al. (2005) collected one M. rajah in this state park, indicating that both species may co-occur in the same area but this needs further confirmation. This species is listed as Least Concern in the IUCN Red List of Threatened Species (Aplin et al. 2008a) and Red List of Mammals for Peninsular Malaysia (DWNP 2010).

Maxomys whiteheadi (Thomas, 1894): We trapped two individuals of this species near Gua Ikan (limestone area) but Francis (2008) stated that generally, this species can be found in tall and old secondary forests and occasionally encroaching disturbed areas in the vicinity of these forests. Wilson et al. (2006) trapped this species in an acacia plantation and a fragmented forest in Borneo. There was also a record of this species occurring in mangrove swamp and secondary forest at Kuala Selangor State Park (Chuluun et al. 2005). This species is listed as Vulnerable in the IUCN Red List of Threatened Species (Aplin et al. 2008b) due to significant population decline for the past 10 years but is listed as Least Concern in the Red List of Mammals for Peninsular Malaysia (DWNP 2010).

Sundamys muelleri (Jentink, 1879): This species has a wide distribution and was normally caught near rivers (Francis 2008). Incidentally, this big rodent was caught in the limestone area of Gua Ikan where there is a river flowing into the cave. Previously this species was caught by Lim (1970) at Sungai Durian Forest Reserve and Mariana et al. (2005) in Gunung Stong State Park. In Borneo this species was caught on the ground or low trees (Wilson et al. 2006). Zakaria et al. (2011) found that this species can survive in disturbed habitats. Ruedas et al. (2008a) assigned the status Least Concern for this species in the IUCN Red List of Threatened Species which was congruent with the Red List of Mammals for Peninsular Malaysia (DWNP 2010).

Niviventer cremoriventer (Miller, 1900): Only one $N$. cremoriventer was caught in this survey at Site A. This species has been recorded in tall and secondary 
forests, forest area and lightly wooded areas (Francis 2008). Lim et al. (2008) trapped this species in a disturbed secondary forest at Lakum Forest Reserve, Pahang. In Mount Nuang Hulu Langat, this species has been recorded right up to $1350 \mathrm{~m}$ asl (Shukor et al. 2001; Batin et al. 2002) and Francis (2008) mentioned that this species can be found up to $1900 \mathrm{~m}$ asl. This species is listed as Vulnerable in the IUCN Red List of Threatened Species due to significant population decline for the past 10 years (Ruedas et al. 2008b) and is listed as Least Concern in the Red List of Mammals for Peninsular Malaysia (DWNP 2010).

Leopoldamys sabanus (Thomas, 1887): We collected a total of six individuals from both trapping sites, dominating non-volant small mammal captures in this study. This species is common in many types of forests in Malaysia and is threatened by clearing of forests (Lim et al. 2008). Individuals of this species were found to be highly infested with ectoparasites and previously Mariana et al. (2005) recorded ticks, Mesostigmatid mites and chiggers on individuals trapped in this same area. It is listed as Least Concern in the IUCN Red List of Threatened Species (Lunde et al. 2008) and Red List of Mammals for Peninsular Malaysia (DWNP 2010).

\section{DISCUSSION}

This survey recorded 11 species of bats and six species of non-volant small mammals with one new record for Kelantan (Myotis muricola) and four additional distributional records for Gunung Stong State Park (Cynopterus horsfieldii, C. sphinx and Penthetor lucasi). Bats from the family Pteropodidae dominated the captures as compared to Shukor et al. (2005) and Mariana et al. (2005) who recorded more insectivorous bats. Leopoldamys sabanus (six individuals) dominated the captures for non-volant small mammals followed by Maxomys whiteheadi (two individuals), while the remaining species ( $M$. surifer, S. muelleri N. cremoriventer and Callosciurus sp.) recorded only one individual each. This in-turn increased the total number of small mammals known to occur in Gunung Stong State Park from 28 species to 35 species.

The sampling effort for this survey was not adequate in documenting total chiropteran community at Gunung Stong State Park as the graph is yet to reach and asymptotic level. In Kuala Lompat, Krau Wildlife Reserve, a total of 837 harp-trap nights and 1573 net hours ( 786 hours for ground nets, 606 hours for stacked nets, 147 hours for canopy nets and 34 hours for river nets) were needed to document total insectivorous bat diversity (Kingston et al. 2003). Hall et al. (2004)

Table 2. List of species caught, net nights and capture rate of non-volant small mammals in this study

\begin{tabular}{|c|c|c|c|c|c|}
\hline Species & Site 1 & Site 2 & Total & Shukor et al. 2005 & Mariana et al.2005 \\
\hline \multicolumn{6}{|l|}{ Muridae } \\
\hline Rattus tiomanicus & 0 & 0 & 0 & 0 & 8 \\
\hline Maxomys whiteheadi & 0 & 2 & 2 & 4 & 7 \\
\hline Maxomys surifer & 0 & 1 & 1 & 3 & 1 \\
\hline Maxomys rajah & 0 & 0 & 0 & 1 & 3 \\
\hline Sundamys muelleri & 0 & 1 & 1 & 0 & 3 \\
\hline Niviventer cremoriventer & 1 & 0 & 1 & 6 & 6 \\
\hline Leopoldamys sabanus & 5 & 1 & 6 & 6 & 6 \\
\hline \multicolumn{6}{|l|}{ Sciuridae } \\
\hline Callosciurus nigrovittatus & 0 & 0 & 0 & 1 & 0 \\
\hline Callosciurus sp. (sighted) & 1 & 0 & 1 & 0 & 0 \\
\hline Total no. of individuals & 7 & 5 & 11 & 21 & 34 \\
\hline No. of species & 3 & 4 & 6 & 6 & 7 \\
\hline No. of family & 2 & 1 & 2 & 2 & 1 \\
\hline Trap-days & 150 & 150 & 300 & 525 & 225 \\
\hline Capture rate & 1 & 1 & 1 & 1 & 1 \\
\hline
\end{tabular}


showed that generally a total effort of 30 net nights was needed to document total fruit bat composition in most areas in southern Thailand, Peninsular Malaysia and Borneo. In this study, the 54 net nights were not adequate in documenting total chiropteran fauna and to compensate this inadequacy, further surveys can be done on a long term basis.

The low trapping rate of harp traps in this study (averaging one individual per night) contributed to the overall low diversity of insect bats captured in this study. Nonetheless our positioning of the harp traps near the forest edge and beside the river may not be effective if the bats do not use the presumed flyways. The low capture rate of non-volant small mammals and the absence of treeshrews and squirrels may be caused by the choice of bait used and trap placement in this study. Previous studies on nonvolant small mammals do indicate bait selection by small mammals, as Bernard (2003) mentioned that the local banana variety 'pisang emas' (Musa acuminata) generally produces the best capture rate. In this study, we used pineapples as bait and the traps were placed on the forest floor which may be selective for trapping rats and treeshrews.

The importance of Gunung Stong State Park for conservation of small mammals is yet to be explored but this recent survey revealed some major findings; First, Gunung Stong State Park is the second known protected area in Malaysia where all four species of Cynopterus that can be found in Peninsular Malaysia (C. brachyotis, $C$. cf. brachyotis Forest, $C$. horsfieldii and sphinx) co-exist. Previous records of such occurrences in Malaysia were only in Perlis State Park and Taiping, Perak (Campbell et al. 2004, 2006). Sungai Dusun may be another area where all four species co-exist but this needs to be confirmed (Abdullah 2003; Hall et al. 2004). Other records of such observations include Thaleban National Park, Thailand (Abdullah 2003; Hall et al. 2004; Abdullah et al. 2007). Abdullah et al. (2007) stated that having three species of Cynopterus netted in the same area was unusual, and they relate their observation way back in 1997 as due to lack of resource partitioning, diet overlap, or similar roosting, emergence time and flight behavior of the species.

The results of this study show that all four species of Cynopterus meet at the ecotones (based on netting results) and such area may be the place where lack of space partitioning between these congenerics occur.
The habitat use of these four species can also be divided into open areas and forested areas, thus we speculate that the existence of such areas together with the ecotones in the vicinity and in Gunung Stong State Park may contribute to the conservation of these fruit bats. Second, this area also recorded three species of Maxomys, with M. rajah and M. whiteheadi listed as Vulnerable in the IUCN Red List of Threatened Species (Aplin et al. 2008 a,b). N. cremoriventer also joins the list of Vulnerable species that can be found in this protected area making Gunung Stong State Park an important area for the conservation of these rodents in peninsular Malaysia. These animals are primarily forest dependent species and are not found outside of forested areas (Aplin et al. 2008a,b; Ruedas et al. 2008b) and are threatened by clearing of forests (Lim et al. 2008), thus protected areas are the only areas where significant conservation planning and effort can be put in place.

The conservation of bats and small mammals are generally overlooked in many protected area management plans in this country except enigmatic species such as the large flying fox Pteropus vampyrus and naked bats Chiromeles torquatus which have some form of economic or aesthetic value. Conservation of small mammals primarily depends on the establishment of protected areas and controlling human activities or disturbance in the vicinity and the protected area itself with good enforcement of local wildlife protection laws. Thus, it is important that knowledge on the diversity of small mammals in protected areas are known for monitoring and management purposes. Gunung Stong State Park as a newly established protected area which requires more data on the diversity and abundance of various taxa including small mammals and it is imperative that relevant institutions such as Universiti Malaysia Kelantan (UMK) support such work by contributing local knowledge on biodiversity in Kelantan. This study is a part of a series of three papers about Kelantan small mammals that will be published based on recent small mammal surveys in the state.

\section{REFERENCES}

Abdullah, M.T. (2003). Biogeography and variation of Cynopterus brachyotis in southeast Asia. PhD Thesis. 
Department of Zoology and Entomology, The University of Queensland, xiv $+233 \mathrm{pp}$.

Abdullah, M.T., M.A. Rahman \& L.S. Hall (1997a). New records for bats in Sarawak, Malaysia. Malayan Nature Journal 50: 365-367.

Abdullah, M.T., H., Siswanto A., Widiyanto, A. Setiabudi \& Firmansyah (1997b). Abundance, diversity and distributional records of bats in disturbed habitats in Kalimantan Barat, Indonesia. Sarawak Museum Journal 51(72): 75-84.

Abdullah, M.T., C. Moritz, G.C. Grigg \& L.S. Hall (2000). Evidence of cryptic species within Cynopterus brachyotis by using mtDNA sequence, pp. 403-408. In: Yaacob, Z., S. Moo-Tan \& S. Yorath (eds.). Proceedings of the International Conference on In-Situ And Ex-Situ Biodiversity Conservation in the New Millenium. Yayasan Sabah, Kota Kinabalu.

Abdullah, M.T., P. Jusanit, P.W.H. Di, M.Z. Ariffin \& L.S. Hall (2007). Observations on bats in three national parks in Thailand. Tiger paper 34(4): 5-10.

Anwarali, F.A.K., S.N. Sazali, V.K. Jayaraj, S. Aban, K.M. Zaini, B. Ketol, J.J.R. Ryan, A.M. Julaihi, L.S. Hall \& M.T. Abdullah (2007). Survey of bats in the tropical lowland dipterocarp forest of Bako National Park, Sarawak, Malaysian Borneo. Sarawak Museum Journal 63(84): 267 300.

Anwarali, F.A.K., V.J. Swier, S. Solari, P.A. Larsen, B. Ketol, W. Marni, S. Ellagupillay, M. Lakim, M.T. Abdullah, \& R.J. Baker (2008). Using genetics and morphology to examine species diversity of Old World bats: report of a recent collection from Malaysia. Occasional Papers, Museum of Texas Tech University 281: 1-28.

Aplin, K., D. Lunde \& G. Musser (2008a). Maxomys surifer. In: IUCN 2011. IUCN Red List of Threatened Species. Version 2011.1. <www.iucnredlist.org>. Downloaded on 30 October 2011.

Aplin, K., D. Lunde, \& L. Ruedas (2008b). Maxomys whiteheadi. In: IUCN 2011. IUCN Red List of Threatened Species. Version 2011.1. <www.iucnredlist.org>. Downloaded on 30 October 2011.

Azlan, J.M., J. Neuchlos \& M.T. Abdullah (2005). Diversity of chiropterans in limestone forest area, Bau, Sarawak. Malaysian Applied Biology 34(1): 59 - 64.

Barapoi, I.P. (2004). Population size estimation of Penthetor lucasi in Wind Cave, Bau, Sarawak. BSc Thesis. Universiti Malaysia Sarawak, Kota Samarahan, Sarawak.

Bates, P., C. Francis, M.Gumal \& S. Bumrungsri (2008a). Cynopterus horsfieldii. In: IUCN (2011). IUCN Red List of Threatened Species. Version 2011.1. <www.iucnredlist. org $>$. Downloaded on 30 October 2011.

Bates, P., S. Bumrungsri, S. Molur \& C. Srinivasulu (2008b). Cynopterus sphinx. In: IUCN 2011. IUCN Red List of Threatened Species. Version 2011.1. <www.iucnredlist. org>. Downloaded on 30 October 2011.

Bates, P., S. Bumrungsri, A. Suyanto, C. Francis, T. Kingston \& I. Maryanto (2008c). Penthetor lucasi. In: IUCN 2011.
IUCN Red List of Threatened Species. Version 2011.1. $<$ www.iucnredlist.org $>$. Downloaded on 30 October 2011.

Bates, P., G. Csorba, S. Bumringsri, T. Kingston, C. Francis, G. Rosell-Ambal, B. Tabaranza, L. Heaney, S. Molur \& C. Srinivasulu (2008d). Myotis muricola. In: IUCN 2011. IUCN Red List of Threatened Species. Version 2011.1. $<$ www.iucnredlist.org > . Downloaded on 30 October 2011.

Bates, P., C. Francis, G. Rosell-Ambal, L. Heaney, S. Molur \& C. Srinivasulu (2008e). Tylonycteris pachypus. In: IUCN 2011. IUCN Red List of Threatened Species. Version 2011.1. <www.iucnredlist.org>. Downloaded on 30 October 2011.

Bates, P., C. Francis, G. Rosell-Ambal\& L. Heaney (2008f). Tylonycteris robustula. In: IUCN 2011. IUCN Red List of Threatened Species. Version 2011.1. <www.iucnredlist. org $>$. Downloaded on 30 October 2011.

Batin, Z., M.N. Shukor \& A.M. Yusoff (2002). Influence of elevational habitat changes on non-volant small mammal species distribution and diversity on Mount Nuang, Hulu, Langat, Selangor Malaysia. Pakistan Journal of Biological Sciences 5(8): 819-824.

Bernard, H. (2003). Bait preferences of some small mammal species of North Borneo based on line-trapping with wiremesh cage traps. Sabah Parks Nature Journal 6: 27-44.

Bourliere, F. (1975). Mammals, small and large: the ecological implications of size, pp. 1-9. In: Golly, F.B., K. Petrusewicza \& L. Ryszkowski (eds.). Small Mammals: Their Productivity and Production. Cambridge University Press, Cambridge.

Campbell, P., C.J. Schneider, A.M. Adnan, A. Zubaid \& T.H. Kunz (2004). Phylogeny and phylogeography of Old World fruit bats in the Cynopterus brachyotis complex. Molecular Phylogenetics and Evolution 33(3): 764-781.

Campbell, P., C.J. Schneider, A.M. Adnan, A. Zubaid \& T.H. Kunz (2006). Comparative population structure of Cynopterus fruit bats in Peninsular Malaysia and southern Thailand. Molecular Ecology 15: 29-47.

Campbell, P., C.J. Schneider, A.M. Adnan, A. Zubaid \& T.H. Kunz (2007). Morphological and ecological correlates of coexistence in Malaysian fruit bats (Chiroptera: Pteropodidae). Journal of Mammalogy 88(1): 105-118.

Chuluun, B., A. Mariana, T. Ho \& B. Mohd Kulaimi (2005). A preliminary survey of ectoparasites of small mammals in Kuala Selangor Nature Park. Tropical Biomedicine 22(2): 243-24.

Csorba, G., S.Bumrungsri, C. Francis, P. Bates, M. Gumal, T. Kingston, S. Molur \& C. Srinivasulu (2008). Cynopterus brachyotis. In: IUCN 2011. IUCN Red List of Threatened Species. Version 2011.1. <www.iucnredlist. org $>$. Downloaded on 30 October 2011.

DWNP (2010). Red List of Mammals For Peninsular Malaysia. Department of Wildlife and National Parks Peninsular Malaysia, 150pp.

Fong, P.H. (2011). Genetic variation and population structure of the genus Cynopterus in Malaysia. MSc Thesis. Universiti Malaysia Sarawak, Kota Samarahan. 
Francis, C.M. (2008). A Guide To The Mammals Of Southeast Asia. New Jersey: Princeton University Press, 392pp.

Francis, C., G. Rosell-Ambal, B. Tabaranza, P. Carino, K. Helgen, S. Molur \& C. Srinivasulu (2008). Eonycteris spelaea. In: IUCN 2011. IUCN Red List of Threatened Species. Version 2011.1. <www.iucnredlist.org>. Downloaded on 30 October 2011.

Hall, L.S., G. Richards \& M.T. Abdullah (2002). The bats of Niah National Park, Sarawak. Sarawak Museum Journal 77(78): 254-281.

Hall, L.S., G.G. Grigg, C. Moritz, B. Ketol, I. Sait, W. Marni \& M.T. Abdullah (2004). Biogeography of fruit bats in Southeast Asia. Sarawak Museum Journal 60(81):191284.

Hutson, A.M., A. Suyanto, T. Kingston, P. Bates, C. Francis, S. Molur \& C. Srinivasulu (2008). Macroglossus sobrinus. In: IUCN 2011. IUCN Red List of Threatened Species. Version 2011.1. <www.iucnredlist.org>. Downloaded on 30 October 2011.

Jayaraj, V.K. (2009). The phylogenetic relationships of Megachiroptera in Malaysia inferred from morphological and DNA analyses. MSc Thesis. Universiti Malaysia Sarawak.

Jayaraj, V.K., B. Ketol, W. Marni, I. Sait, M.J. Mortada, F.A.K. Anwarali, P.H. Fong, L.S. Hall \& M.T. Abdullah (2011). Comparative distribution and diversity of bats from selected localities in Sarawak. Borneo Journal of Resource Science and Technology 1(1): 1-13.

Jayaraj, V.K., C.J. Laman \& M.T. Abdullah (2012). A predictive model to differentiate $C$. brachyotis from $C$. cf. brachyotis Forest (Chiroptera: Pteropodidae) from Malaysia using Multivariate Analysis. Zoological Studies 51(2): 259-271.

Karim, C., A.A. Tuen \& M.T. Abdullah (2004). Mammals. Sarawak Museum Journal Special Issue No. 6(80): 221234.

Kingston, T., C.M. Francis, A. Zubaid \& T.H. Kunz (2003). Species richness in an insectivorous bat assemblage from Malaysia. Journal of Tropical Ecology 19: 67-79.

Kingston, T., B.L. Lim \& Z. Akbar (2006). Bats of Krau Wildlife Reserve. Universiti Kebangsaan Malaysia Publishers, Kuala Lumpur.

Latiff, A. \& I. Faridah-Hanum (2005). Effectiveness of Gunung Stong State Park in protecting biodiversity and promoting education and research in Kelantan, pp. 44-59. In: Shaharudin M.I., T. Dahalan, S.S. Abdullah, M.S. Jalil, I. Faridah-Hanum \& A. Latiff (eds.). Taman Negeri Gunung Stong, Kelantan: Pengurusan, Persekitaran Fizikal, Biologi dan Sosio-Ekonomi. Siri Kepelbagaian Biologi Hutan 5. Jabatan Perhutanan Semenanjung Malaysia, 442pp.

Lim, B.L., K.K.P. Lim \& H.S. Yong (1999). The terrestrial mammals of Pulau Tioman, Peninsular Malaysia, with a catalogue of specimens at the Raffles Museum, National University of Singapore. The Raffles Bulletin of Zoology 6: 101-123.

Lim, B.L., M.K.M. Khan, K.S. Chai \& C.C. Lim (2008),
Pre-logging survey of herpetological and mammal fauna at Lakum Forest Reserve, Raub, Pahang, Malaysia. Journal of Science and Technology in the Tropics 4: 99-116.

Lunde, D., K. Aplin, L. Rueda \& S. Molur (2008). Leopoldamys sabanus. In: IUCN 2011. IUCN Red List of Threatened Species. Version 2011.1. <www.iucnredlist. org $>$. Downloaded on 30 October 2011.

Mariana, A., Z. Zuraidawati, T.M. Ho, B.M. Kulaimi, I. Saleh, M.N. Shukor \& M.S. Shahrul-Anuar (2005). A survey of ectoparasites in Gunung Stong Forest Reserve, Kelantan, Malaysia. Southeast Asian Journal of Tropical Medicine and Public Health 36(5): 1125-1131.

Maseri, N.M. \& A.H. Mohd-Ros (2005). Managing Gunung Stong State Park: A conceptual framework, pp. 31-43. In: Shaharudin M.I., T. Dahalan, S.S. Abdullah, M.S. Jalil, I. Faridah-Hanum \& A. Latiff (eds.). Taman Negeri Gunung Stong, Kelantan: Pengurusan, Persekitaran Fizikal, Biologi dan Sosio-Ekonomi. Siri Kepelbagaian Biologi Hutan 5. Jabatan Perhutanan Semenanjung Malaysia, 442pp.

Pue, G.H. \& A. Latiff (2005). Kepelbagaian dan pengurusan hidupan liar di Kelantan, pp. 253-260. In: Shaharudin M.I., T. Dahalan, S.S. Abdullah, M.S. Jalil, I. Faridah-Hanum \&A. Latiff (eds.). Taman Negeri Gunung Stong, Kelantan: Pengurusan, Persekitaran Fizikal, Biologi dan SosioEkonomi. Siri Kepelbagaian Biologi Hutan 5. Jabatan Perhutanan Semenanjung Malaysia, 442pp.

Rahman, M.R.A. \& M.T. Abdullah (2011). Memecahkan Kod DNA Cecadu Hitam Pudar. Dewan Kosmik, Majalah Sains dan Teknologi, Jun 2011. Dewan Bahasa dan Pustaka, Kuala Lumpur Malaysia, 32-33pp.

Ruedas, L., D. Lunde \& K. Aplin (2008a). Sundamys muelleri. In: IUCN 2011. IUCN Red List of Threatened Species. Version 2011.1. <www.iucnredlist.org>. Downloaded on 30 October 2011.

Ruedas, L., K. Aplin, G. Musser \& D. Lunde (2008b). Niviventer cremoriventer. In: IUCN 2011. IUCN Red List of Threatened Species. Version 2011.1. <www.iucnredlist. org $>$. Downloaded on 30 October 2011.

Shukor, M.N., M.S. Shahrul Anuar, E. Nurul 'Ain, M. Norzalipah, A. Norhayati, A. Nadzri, Y. Ahmed, O. Mohd Yusof, M. Ganesan \& S. Kalimuthu (2005). Tinjauan mamalia kecil di Hutan Simpan Gunung Stong, pp. 227-236. In: Shaharudin M.I., T. Dahalan, S.S. Abdullah, M.S. Jalil, I. Faridah-Hanum \&A. Latiff (eds.). Taman Negeri Gunung Stong, Kelantan: Pengurusan, Persekitaran Fizikal, Biologi dan Sosio-Ekonomi. Siri Kepelbagaian Biologi Hutan 5. Jabatan Perhutanan Semenanjung Malaysia, 442pp.

Simmons, N.B. (2005). Order Chiroptera, pp. xx-xx. In: Wilson, D.E. \& D.M. Reeder (eds.). Mammal species of the World: A Taxonomic and Geographical Reference-3 $3^{\text {rd }}$ Edition. Smithsonian Institution Press, Washington D.C.

Storz, J.F., H.R. Bhat \& T.H. Kunz (2000). Social structure of a polygynous Tent-making Bat, Cynopterus sphinx (Megachiroptera). Journal of Zoology 251: 151-165.

Storz, J.F., H.R. Bhat \& T.H. Kunz (2001). Genetic consequences of polygyny and social structure in an Indian 
Fruit Bat, Cynopterus sphinx. II. Variance in male mating success and effective population size. Evolution 55: 1224-1232.

Struebig, M.J., S.J., Rossiter, P.J.J. Bates, T. Kingston, S.S.L. Oo, A.A. Nwe, M.M. Aung, S.S. WIN \& K.M. Mya (2005). Results of a recent bat survey in Upper Myanmar including new records from the Kachin forests. Acta Chiropterologica 7(1): 147-163.

Struebig, M.J., B.M.F. Galdikas \& Suatma (2006). Bat diversity in oligotrophic forests of southern Borneo. Oryx 40(4): 1-13.

Walker, S. \& A. Rabinowitz (1992). The small-mammal community of a dry-tropical forest in central Thailand. Journal of Tropical Ecology 8: 57-71.

Walston, J., T. Kingston \& A.M. Hutson (2008). Rhinolophus affinis. In: IUCN 2011. IUCN Red List of Threatened Species. Version 2011.1. <www.iucnredlist. org >. Downloaded on 30 October 2011.

Wilson, D.E., K.M. Helgen, C.S. Yun \& B. Giman (2006). Small mammal survey at two sites in planted forest zone, Bintulu, Sarawak. Malayan Nature Journal 59(2): 165-187.

Yusoff, M.K., R. Harun, A. Muda, A.R. Haron, J.N. Jahaya, M. Z. Ismail, N.S. Mohd Resali, N.A. Khairuddin \& M. Mohammad (2005). Status kualiti air di Hutan Simpan Kekal Gunung Stong, pp. 81-90. In: Shaharudin M.I., T. Dahalan, S.S. Abdullah, M.S. Jalil, I. Faridah-Hanum \&A. Latiff (eds.). Taman Negeri Gunung Stong, Kelantan: Pengurusan, Persekitaran Fizikal, Biologi dan SosioEkonomi. Siri Kepelbagaian Biologi Hutan 5. Jabatan Perhutanan Semenanjung Malaysia, 442pp.

Zafir, A.W.A., A.K. Johanssen, M.R. Darmaraj, O. Ansel, D.S.K. Sharma \& S. Suksuwan (2005). Camera-trapping and observations of the larger animals West Kelantan Forests complex, pp. 246-252. In: Shaharudin M.I., T. Dahalan, S.S. Abdullah, M.S. Jalil, I. Faridah-Hanum \& A. Latiff (eds.). Taman Negeri Gunung Stong, Kelantan: Pengurusan, Persekitaran Fizikal, Biologi dan Sosio-Ekonomi. Siri Kepelbagaian Biologi Hutan 5. Jabatan Perhutanan Semenanjung Malaysia, 442pp.

Zakaria, M., N. Musa \& M.M. Top (2011). Composition of non-volant small mammals in different ages of rehabilitated forest. Rehabilitation of Tropical Rainforest Ecosystems 24-25 October 2011, Kuala Lumpur. Universiti Putra Malaysia - Mitsubishi Corporation, 169-178pp.
Author Details: ViJAYA Kumaran JaYARAJ is Malaysian mammalogists currently attached to Universiti Malaysia Kelantan who has regularly written and publish papers on small mammal diversity in Malaysia. He is currently pursuing his $\mathrm{PhD}$ on phylogeographic relationship of treeshrews in Peninsular Malaysia at Universiti Sains Malaysia under the supervision of Associate Professor Dr. Ahmad Sofiman Othman and Associate Professor Dr. Sharul Anuar Mohd Sah.

Nurul Farah Diyana Ahmad TahiR, Noor Amirah Udin, NoOR Farahin Kamarul Baharin, SitI KaTIJAH ISMAIL and SITI NOOR AZWA ZaKaria are all students pursuing their BSc (Hons) in Natural Resource Management at Universiti Malaysia Kelantan.

Acknowledgements: The principle investigator Jayaraj Vijaya Kumaran would like to thank Professor Dr. Mohd. Tajuddin Abdullah and Isham Azhar for their comments and suggestions in improving the draft of this paper. He would also like to thank Siti Hajar Muhamad Daud for her help in getting the GPS reading for Gua Ikan and Miss Fong Pooi Har for the assistance during reexamination of specimens. We extend our gratitude to Universiti Malaysia Kelantan (UMK) for various administrative and logistic supports and we would also like to thank the management of Gunung Stong State Park for their support and hospitality throughout the survey. This study was actually a class activity for the subject Park and Protected area Management and we would like to thank $\mathrm{Mr}$. Mohamad RohanifMohamedAli, Mr. Muhammad Che Isa, Miss. Nur Aiashah Ibrahim, Miss. Nur Izzati Salleh, Miss. Zalina Che Man, Natural Resource Science students and all those who were involved for their effort in making this a successful event. We would also like to thank the Department of Wildlife and National Parks (PERHILITAN) for approval to conduct research on wildlife in Kelantan. The quality of this paper has also been significantly improved by the critical comments of an anonymous reviewer and we are grateful to him for his contribution. This study was partially funded by two grants namely Ministry of Higher Education Fundamental Research Grant (MOHE FRGS: R/FRGS/A03.00/00481A/002/2011/000043) awarded to Jayaraj Vijaya Kumaran, Zulhazman Bin Hamzah, Professor Dr. Mohd Tajuddin Abdullah, Dr. Yuzine Esa, Faisal Ali Anwarali Khan and Jeffrine Rovie Ryan Japning and Universiti Malaysia Kelantan Short Term Grant (UMK SGJP: R/SGJP/ A03.00/00481A/001/2010/000037) awarded to Jayaraj Vijaya Kumaran, Dr. Wong Yee Ching and Dr. Abdul Rahman Aziz. 